\title{
KAJIAN YURIDIS PENGESAMPINGAN PASAL 1266 DAN PASAL 1267 KITAB UNDANG-UNDANG HUKUM PERDATA SEBAGAI SYARAT BATAL DALAM PERJANJIAN KREDIT PERBANKAN
}

\author{
Rocky Marciano Ambar \\ Budi Santoso \\ Hanif Nur Widhiyanti \\ Magister Kenotariatan Fakultas Hukum Universitas Brawijaya \\ Jalan Veteran, Malang 65145, Indonesia \\ rocky.ambar@yahoo.co.id
}

\begin{abstract}
Banks in the redit agreement use more standardized credit agreements, the use of standard contracts in the banking credit agreement is based on 2 (two) things, (1) The existence of unbalanced position (berganing position) between banks and the debtor, the bank has a more dominant position than the debtor. (2) There is an understanding of the principle of freedom of contract absolutely and indefinitely so that the bank has absolute freedom to determine the form and content of the agreement. So banks can freely to determine the form and contents of the agreement included in the clause of the terms of void wanprestasi arranged to include mengesaampinkan Article 1266 and Article 1267 Civil Code in the agreement. Whereas the provision of Article 1266 of the Civil Code provides that in the event that the revocation of the treaty must be requested by the court and the judge through the decision of the court may determine the types of compensation for the parties. Based on the background, then as for the formulation of the problem of writing is (1). Whether the inclusion of clause 1266 and Article 1267 of the Civil Code in the credit agreement of the banking system has fulfilled the principle of equilibrium and justice. (2) What is the juridical implication of the inclusion of clauses which exclude Article 1266 and Article 1267 of the Civil Code in the credit agreement pertaining to the debtor's right in the process of settling the interpretation as a condition of cancellation of the agreement. The research method used is normative juridical research. The result of this research is the waiver of Article 1266 and Article 1267 of the Civil Code which regulates the waiprestasi void in the agreement and the types of indemnity is contrary to the principle of fairness and the principle of equilibrium. The principle of justice according to Rawls is that it is unfair to sacrifice the right of one or more persons only for the sake of greater economic gain and even justice must be understood as fairness, in the sense of "equality of positions and rights" not in the sense of "commonality of results" people, in other words justice as intended is justice that provides a guarantee of equality and rights between the bank as a creditor with the customer as a debtor in the credit agreement of the bank. As for the juridical implication of the inclusion of clauses that exclude Article 1266 and Article 1267 of the Civil Code of credit agreement relating to the debtor's right in the process of settling the interpretation as a condition is to remove the legal rights as well as the debtor's legal efforts in seeking justice and the equilibrium position which is not dominant by the decision maker due to the unbounded imbalance of the parties to the agreement. The act of wanprestation brings consequences to the adversity of the disadvantaged party to prosecute the defendant to indemnify, so that by law it is expected that none of the parties will be harmed by the default.
\end{abstract}

Keywords: Article 1266 and Article 1267 Civil Code, Terms of Cancel, Credit Agreemen. 


\section{Pendahuluan}

Hukum sebagai suatu sistem yang memuat berbagai aturan terkait tingkah laku manusia dalam kelompok masyarakat pada prinsipnya bertujuan untuk menciptakan ketertiban dan keadilan serta keteraturan hidup di dalam masyarakat. Hal ini sesuai dengan adagium ubi societas ubi ius yang artinya di mana ada masyarakat disitu ada hukum atau keadilan.

Secara kodrati, disamping sebagai makhluk individu manusia juga merupakan makhluk sosial yang dalam memenuhi kebutuhannya tidak dapat hidup sendiri tanpa bantuan dari individu yang lainya. Kondisi demikian selanjutnya dapat memunculkan kesepakatan-kesepakatan kehendak antara yang satu dengan yang lainya sebagai upaya untuk memenuhi kebutuhannya disegala aspek kehidupan. Kesepakatan kehendak dalam kehidupan seharihari dikenal dengan istilah perjanjian, baik yang dibuat bersifat lisan maupun tulisan, yang dalam konteks hukum perdata disebut sebagai hukum perjanjian. ${ }^{1}$

Hukum perjanjian dalam sistem hukum Indonesia diatur dalam buku

III Kitab Undang-Undang Hukum Perdata (Burgerlijk Wetboek), yang merupakan hukum yang bersifat khusus dalam melakukan perjanjian dan perbuatan hukum yang bersifat ekonomis atau perbuatan hukum yang dapat dinilai dari harta kekayaan seseorang atau badan hukum. Buku III KUHPerdata menganut sifat terbuka dan asas kebebasan berkontrak, sifat terbuka dan asas kebebasan berkontrak yang dimaksud di mana para pihak boleh membuat perjanjian dengan siapa saja dan tentang hal apa yang akan diperjanjikan. Namun, harus dipahami bahwa kebebasan berkontak sebagaimana diatur pada Pasal 1338 KUHPerdata bukan merupakan asas bebas mutlak, KUHPerdata sendiri memberikan pembatasan-pembatasan atas asas kebebasan berkontrak walaupun dalam perkembangan dunia bisnis penerapan asas kebebasan berkontrak sangat longgar dan bervariasi yang di mana perbedaan dalam penerapan ini telah menimbulkan ketimpanganketimpangan dan ketidakadilan apabila para pihak yang membuat perjanjian

\footnotetext{
${ }^{1}$ Ratna Artha Windari, Hukum Perjanjian, Yogyakarta: Graha Ilmu, 2014, hlm. 1.
} 
tidak dalam posisi yang sama kuat kedudukannnya atau mempunyai bargaining position yang tidak sama. ${ }^{2}$

Perjanjian dengan klausula baku merupakan salah satu bentuk perjanjian yang mengandung unsur ketimpangan-ketimpangan yaitu cenderung berat sebelah, tidak seimbang dan adil, diibaratkan dengan pertarungan antara "seorang kesatria dengan orang biasa" di mana berhadapan dua kekuatan yang tidak seimbang, antara pihak yang mempunyai bargaining position pihak yang kuat baik karena penguasa, pemilik modal, dana, dan teknologi ataupun skill dengan pihak yang lemah bargaining postion-nya. Dengan demikian, pihak yang lemahbargaining postion-nya hanya sekadar menerima segala isi perjanjian dengan terpaksa (taken for granted) sebab apabila melakukan tawaran dengan alternatif lain kemungkinan besar akan menerima konsekuensi kehilangan apa yang dibutuhkan bahkan pihak yang lemah hanya diberikan dua alternatif pilihan yaitu menerima atau menolak (take it or leave it). ${ }^{3}$

Fenomena terjadinya ketimpangan dalam perjanjian kredit dapat dicermati dari beberapa model perjanjian, terutama pada perjanjian-perjanjian yang dibuat antara bank dengan debitur dalam bentuk perjanjian kredit baku di mana dalam perjanjian tersebut selalu mencantumkan klausula-klausula yang "cenderung" berat sebelah. Praktik pemberian kredit di lingkungan perbankan, bank sebagai pihak yang memilik posisi kuat sering mencantumkan klausula mewajibkan nasabah untuk tunduk kepada segala petunjuk dan peraturan bank, baik yang sudah ada atau yang akan diatur kemudian, bahkan klausula yang membebaskan bank dari kerugian nasabah sebagai akibat dari tindakan bank. ${ }^{4}$

Terhadap perjanjian baku, terdapat klausula yang menghapus hakhak hukum debitur, seperti klaulusa perjanjian kredit baku yang mengesampingkan Pasal 1266 dan Pasal 1267 KUHPerdata sebagai syarat

\footnotetext{
${ }^{2}$ Daeng Naja, Contract Drafting, Bandung: PT. Citra Aditya Bakti, hlm. 11.

${ }^{3}$ Agus Yudha Hernoko, Hukum Perjanjian Asas Proposionalitas dalam Kontrak Komersial, Jakarta: Kencana. 2010, hlm. 2.

${ }^{4}$ Ibid., hlm. 3 .
} 
batal jika terjadi wanprestasi. Pasal 1266 dan Pasal 1267 KUHPerdata merupakan ketentuan yang sifatnya memaksa dikarenakan ada kata "harus" dalam melakukan permohonan pembatalan kepada hakim atau melalui pengadilan, oleh sebab itu Pasal 1266 dan Pasal 1267 KUHPerdata adalah ketentuan hukum yang tidak dapat disampingkan dalam suatu perjanjian. Suharnoko dalam bukunya Hukum Perjanjian: Teori dan Analisa Kasus memiliki pendapat yang sedikit moderat. Pasal 1266 KUHPerdata tidak dapat disampingkan dalam semua kasus.

Pengesampingan Pasal 1266 dan Pasal 1267 KUHPerdata lebih memberikan posisi yang menguntungkan bagi bank selaku kreditur, di mana kreditur akan lebih efesien dan tidak perlu untuk menunggu adanya putusan pengadilan untuk melakukan tindakan-tindakan dalam memenuhi haknya dengan prosesnya yang berlarut-larut, dan tidak merugikan kreditur. Namun, pada posisi yang lain pengesampingan Pasal 1266 dan Pasal 1267 KUHPerdata pada saat terjadinya wanprestasi menimbulkan beberapa permasalahan hukum, yaitu pengesampingan Pasal 1266 KUHPerdata adalah bertentangan dengan Pasal 1266 KUHPerdata itu sendiri, Pasal 1266 KUHPerdata merupakan ketentuan yang tidak dapat disampingkan sebagaimana tercantum pada pasal tersebut bahwa dalam hal terjadinya wanprestasi maka pembatalan perjanjian harus dimintakan ke pengadilan. Sedangkan pengesampingan Pasal 1267 KUHP perdata adalah penghapusan atas hak-hak debitur untuk melakukan gugatan hukum ganti rugi kepada bank, dengan demikian debitur tidak memiliki hak-hak hukum melalui pengadilan untuk memintakan bentuk suatu ganti rugi kepada bank atas tindakan-tindakan bank yang merugikan debitur. 


\section{Rumusan Masalah}

2.1. Apakah pencantuman klausula pengesampingan Pasal 1266 dan Pasal 1267 Kitab Undang-Undang Hukum Perdata dalam perjanjian kredit perbankan telah memenuhi asas keadilan dan asas keseimbangan.

2.2. Bagaimana implikasi yuridis pencantuman klausula yang mengesampingkan Pasal 1266 dan Pasal 1267 Kitab Undang-Undang Hukum Perdata dalam perjanjian kredit perbankan terkait dengan hak debitur dalam proses penyelesaian wanpretasi sebagai syarat pembatalan perjanjian.

\section{Tujuan Penelitian}

3.1. Untuk menganalisis pencantuman klausula mengesampingkan Pasal 1266 dan Pasal 1267 Kitab Undang-Undang Hukum Perdata dalam perjanjian kredit perbankan telah memenuhi asas keseimbangan dan keadilan.

3.2. Untuk menganalisis implikasi yuridis pencantuman klausula yang mengesampingkan Pasal 1266 dan Pasal 1267 Kitab Undang-Undang Hukum Perdata dalam perjanjian kredit perbankan terkait dengan hak debitur dalam proses penyelesaian wanprestasi sebagai syarat batal dalam perjanjian.

\section{Metode Penelitian}

Dalam penelitian ini, digunakan metode penelitian hukum normatif. Sedangkan pendekatan yang digunakan adalah pendekatan perundangundangan (statute approach). Jenis bahan hukum yang digunakan ialah bahan hukum primer, sekunder, dan tersier. Teknik memperoleh data pada penelitian ini adalah dengan melakukan studi pustaka (library research). 


\section{Hasil Penelitian dan Pembahasan}

\subsection{Pengesampingan Pasal 1266 dan Pasal 1267 KUHPerdata Pada Perjanjian Kredit Perbankan dalam Kajian Asas Keadilan}

Keadilan adalah tujuan utama hukum. "Hukum adalah kehendak demi untuk keadilan" kata Gustav Radbruch (Recht Ist Wille Zur Gerechtigkeit). Pertanyaan seputar apa itu "keadilan" adalah suatu pertanyaan yang sering didengar, demikian juga dengan para ahli, dalam memberikan pengertian tentang apa arti keadilan itu memiliki keberagaman.

Keadilan menurut Upianus, ${ }^{5}$ adalah sebagai “Justitia Est Constans Et Perpetua Voluntas Ius Suum Cuique Tribuendi" (keadilan adalah kehendak yang terus-menerus dan tetap memberikan kepada masingmasing apa yang menjadi haknya) atau "Tribuere Cuique Suum" "To Give Everybody His Own”, memberikan kepada setiap orang yang menjadi haknya. Perumusan ini dengan tegas mengakui hak masingmasing person terhadap lainnya serta apa yang harus menjadi bagiannya, demikian pula sebaliknya. Justianus ${ }^{6}$ dalam corpus luris civilis: juris praecepta sunt haec: honeste vivere, alterum non laedere, suum cuique tribuere, bahwa peraturan-peraturan dasar dari hukum adalah terkait dengan hidup dengan patut, tak merugikan orang lain dan memberatkan orang lain apa yang menjadi bagiannya.

Sedangkan Rawls dalam penadangannya adalah tidak adil mengorbankan hak dari satu atau beberapa orang hanya demi keuntungan ekonomis yang lebih besar bagi masyarakat secara keseluruhan. Sikap ini justru bertentangan dengan keadilan sebagai fairness, yang menurut prinsip kebebasan yang sama sebagai basis yang melandasi pengaturan kesejahteraan sosial. $^{7}$ Oleh karenanya pertimbangan ekonomis tidak boleh bertentangan dengan prinsip kebebasan dan hak yang sama bagi semua orang. Keputusan sosial yang

${ }^{5}$ O. Notohamidjojo, Masalah: Keadilan, Semarang, Tirta Amerta, 1971, hlm. 18-19.

${ }^{6}$ Ibid., hlm. 9.

${ }^{7}$ Agus Yudha Hernoko, Op. Cit., hlm. 55-56. 
mempunyai akibat bagi semua orang atau masyarakat harus dibuat atas dasar hak (right based weight) daripada atas dasar manfaat (good-based weight). Dengan demikian keadilan sebagai fairness dapat dinikmati oleh semua orang. Dalam konteks ini yang dimaksud Rawls adalah "justice as fairness" yang ditandai adanya prinsip rasionalitas, kebebasan, dan kesamaan. Oleh karena itu, diperlukan prinsip-prinsip keadilan yang lebih mengutamakan asas hak daripada asas manfaat.

Berdasarkan uraian di atas maka penulis menggarisbawahi bahwa konsep kedilan sebagaimana pandangan Rawls harus dipahami sebagai fairness, dalam arti "kesetaraan kedudukan dan hak" bukan dalam arti "kesamaan hasil" yang dapat diperoleh semua orang. Di mana kesamaan hasil bukanlah suatu alasan untuk membenarkan prosedur atau hukum.

Pembasahan tentang hubungan kontraktual para pihak hakekatnya tidak dapat dilepaskan dalam hubungannya dengan masalah keadilan. Kontrak atau perjanjian sebagai wadah yang mempertemukan kepentingan satu pihak dengan pihak yang lain menuntut bentuk pertukaran kepentingan yang adil.

Menurut Subekti, jika pelaksanaan perjanjian menurut hurufnya, akan memunculkan ketidakadilan, maka hakim mempunyai kewenangan untuk menyimpang dari isi perjanjian menurut hurufnya. ${ }^{8}$

Dengan demikian jika pelaksanaan suatu perjanjian menimbulkan ketidakseimbangan atau melanggar rasa keadilan, maka hakim dapat mengadakan penyesuaian terhadap hak dan kewajiban yang tercantum dalam perjanjian yang dibuat oleh para pihak. Hakim berdasarkan itikad baik, menggunakan kewenangan untuk mencampuri isi perjanjian, sehingga tampaknya itikad baik bukan saja harus ada pada pelaksanaan perjanjian, melainkan juga pada saat dibuatnya atau ditandatanganinya perjanjian.

${ }^{8}$ Suharnoko, Hukum Perjanjian Teori dan Analisa Kasus, Cetakan Kedua 2004. Jakarta, Kencana Prenada Media Group. 2004, hlm. 4. 
Dikaitkan dengan perjanjian kredit baku pada dunia perbankan dalam klausula perjanjian yang mengesampingkan Pasal 1266 dan Pasal 1267 KUHPerdata yaitu sebagai upaya dalam penyelesaian perkara melalui lembaga peradilan untuk mencari keadilan fairness atau sebagai pure procedure justice tidak menuntut setiap orang yang terlibat dan menempuh prosedur yang sama juga harus mendapat hasil yang sama. Sebaliknya, hasil prosedur yang fair itu harus diterima sebagai adil juga apabila setiap orang tidak mendapatkan hasil yang sama. Namun keadilan yang dimaksud adalah memberikan suatu hak mendasar dan kedudukan hukum yang sama bagi setiap nasabah dan debitur dalam setiap perbuatan hukum.

Pasal 1266 KUHPerdata adalah merupakan suatu aturan hukum yang bersifat wajib dalam arti para pihak dalam perjanjian timbal balik tidak dapat mengesampingkan dan melepaskan diri dari Pasal 1266 KUHPerdata dalam klausula perjanjian yang dibuat, bahkan dalam ketentuan ini dalam hal terjadi wanpretasi perjanjian yang dibuat tidak secara otomatis batal tetapi harus diajukan kepada hakim untuk memperoleh suatu pembatalan baik atas pembatalan perjanjian ataupun dalam hal ganti rugi sebagai akibat yang ditimbulkan dari perjanjian yang telah dibuat oleh para pihak.

Dalam teori keadilan sebagimana telah penulis uraikan bahwa keadilan fairness atau sebagai pure procedure justice mendasari pada terwujudnya perlindungan hak dan kedudukan yang sama dalam suatu perbuatan hukum. Oleh sebab itu perjanjian kredit baku yang diterbitkan oleh bank selaku kreditur di mana debitur hanya didudukkan pada posisi yang pasif dengan klausula yang mengesampingkan Pasal 1266 dan Pasal 1267 KUHPerdata sebagai syarat batal adalah menghapus hak-hak hukum debitur dan bertentangan dengan teori keadilan yaitu keadilan fairness atau sebagai pure procedure justice. 


\subsection{Pengesampingan Pasal 1266 dan Pasal 1267 KUHPerdata pada Perjanjian Kredit Perbankan dalam Kajian Asas Keseimbangan}

Asas kesimbangan dalam suatu perjanjian kredit perbankan diperlukan untuk menyeimbangkan kepentingan para pihak yang terikat pada suatu perjanjian yang dibuat. Dalam hal ini asas kesimbangan adalah keadaan hening atau keselarasan karena dari berbagai gaya yang bekerja tidak satu pun mendominasi yang lainya atau karena tidak satu elemen menguasai yang lainnya.

Asas keseimbangan dalam perjanjian kredit dijabarkan dalam perumusan hak dan kewajiban para pihak, sebagai indikator penentu penjabarannya tampak pada posisi seimbang antara hak dan kewajiban masing-masing pihak dalam perjanjian kredit. Keseimbangan para pihak hanya akan terwujud apabila para pihak berada pada posisi yang sama kuat, namun bank sebagai pihak yang dominan sedangkan nasabah pelaku usaha kecil sebagai pihak yang lemah keseimbangan sulit terwujud.

Dalam asas keseimbangan menghendaki kedua pihak memenuhi dan melaksanakan perjanjian itu. Asas keseimbangan merupakan kelanjutan dari asas persamaan. Kreditur mempunyai kekuatan untuk menuntut prestasi jika diperlukan dapat menuntut pelunasan prestasi melalui kekayaan debitur, namun kreditur memikul beban untuk melaksanakan perjanjian itu dengan itikad baik, sehingga kedudukan kreditur dan debitur seimbang. Kerja Asas keseimbangan yang optimal akan menyeimbangkan kepentingan pihak-pihak, memberikan hukum yang ideal bagi para pihak dan memberikan keadilan dalam perjanjian sebagaimana yang telah dibuat oleh para pihak. Oleh sebab itu, suatu perjanjian kredit perbankan sangatlah beralasan selain melandasi pada asas-asas umum perjanjian lainya haruslah mendasari pada asas keseimbangan di mana memberikan suatu jaminan atas posisi yang sama antara debitur dan kreditur. 
Adapun tiga aspek yang dapat digunakan dalam menguji berlakunya asas kekseimbangan dalam suatu perjanjian, yaitu:

5.2.1. Perbuatanya sendiri atau pelaku individual;

5.2.2. Isi kontrak;

5.2.3. Pelaksanaan dari apa yang telah disepakati.

Hal yang selalu dikedepakan dengaan asas kesimbangan dalam suatu penyusunan perjanjian kredit pada suatu bank adalah adanya asas kebebasan berkontrak di mana dipahami para pihak dapat dengan leluasa membuat suatu perjanjian. Kebebasan berkontrak sebagaimana menjadi rumusan dasar para pihak dalam melakukan suatu hubungan hukum baik antara bank selaku kreditur dengan nasabah selaku debitur harus berpangkal pada kedudukan kedua belah pihak yang sama kuatnya, sehingga dapat mewujudkan suatu kesimbangan dalam kepentingan masing-masing, sedangkan dalam kenyataanya seringkali tidaklah demikian.

Kedudukan para pihak yang tidak seimbang yakni tidak sama kuat kedudukannya atau tidak mempunyai bargaining position yang sama telah mempengaruhi daya kerja asas kebebasan berkontrak sehingga menimbulkan ketimpangan-ketimpangan dan ketidakadilan dalam pengaturan hak dan kewajiban para pihak dalam perjanjian.

Pembatasan hak dan ketidakseimbangan kedudukan dalam perjanjian sering terjadi pada perjanjian kredit perbankan, bank telah menyusun secara sepihak setiap perjanjian kredit yang nantinya akan mengikat dan berlaku bagi bank itu sendiri dengan debitur. Posisi yang tidak seimbang antara bank dengan calon debitur memberikan kedudukan yang menguntungkan bagi bank, hal ini yang melatarbelakangi hadirnya suatu perjanjian baku dalam perjanjian kredit dengan klausula-klausula yang telah ditentukan secara sepihak oleh bank. 
Perjanjian kredit baku perbankan yang menjadi kajian penulis adalah perjanjian kredit baku dengan klausula yang mengesampingkan Pasal 1266 dan Pasal 1267 KUHPerdata sebagai syarat batal dalam suatu perjanjian. Pasal 1266 KUHPerdata menegaskan bahwa dalam hal terjadinya wanprestasi dapat dilakukan upaya pembatalan atau ganti rugi sebagai akibat dari suatu perjanjian yang telah dibuat pada pengadilan. Tentunya Pasal 1266 KHUPerdata memberikan penegasan bahwa bukan merupakan suatu hal yang dapat ditawar-menawar penyelesaian masalah wanpretasi melalui lembaga pengadilan, namun dalam kenyataannya pada perjanjian kredit baku Pasal 1266 dan Pasal 1267 KUHPerdata dengan tegas disampingkan dan dinyatakan tidak berlaku.

Pengesampingan Pasal 1266 dan Pasal 1267 KUHPerdata dalam suatu perjanjian baku kredit perbankan ini juga menggambarkan dan membuktikan bahwa adanya akibat yang tidak adil dimana tidak memberikan suatu kedudukan yang seimbang bagi para pihak dalam kedudukan hukum maupun hak dan kewajiban yang ditimbulkan oleh perjanjian yang dibuat, sedangkan dalam konteks asas keseimbangan dalam suatu perjanjian kredit perbankan adalah agar dapat menyeimbangkan kepentingan para pihak yang terikat pada suatu perjanjian yang dibuat atau dengan kata lain terciptanya suatu keselarasan di mana tidak ada satu pun mendominasi yang lainya atau karena tidak satu elemen menguasai yang lainnya.

\subsection{Implikasi Yuridis Pencantuman Klausula yang Mengesampingkan} Pasal 1266 dan Pasal 1267 Kitab Undang-Undang Hukum Perdata dalam Perjanjian Kredit Perbankan Terkait dengan Hak Debitur dalam Proses Penyelesaian Wanprestasi sebagai Syarat Batal Perjanjian.

Perikatan yang bersifat timbal balik senantiasa menimbulkan sisi aktif dan sisi pasif. Sisi aktif menimbulkan hak bagi kreditur untuk menuntut pemenuhan prestasi, sedangkan sisi pasif menimbulkan beban 
kewajiban bagi debitur untuk melaksanakan prestasinya. Pada situasi normal antara prestasi dan kontra prestasi akan salin bertukar, namun pada kondisi tertentu pertukaran prestasi tidak berjalan sebagaimana mestinya sehingga muncul peristiwa yang disebut wanprestasi. Pelanggaran hak-hak kontraktual tersebut menimbulkan kewajiban ganti rugi berdasarkan wanprestasi, sebagaimana diatur dalam Pasal 1236 KUHPerdata (untuk prestasi memberikan sesuatu) dan Pasal 1239 KUHPerdata (untuk prestasi berbuat sesuatu).

Wanprestasi (breach of contract) adalah tidak dilaksanakannya prestasi atau kewajiban sebagaimana mestinya yang dibebankan oleh kontrak terhadap pihak-pihak tertentu seperti yang disebutkan dalam kontrak yang bersangkutan. Tindakan wanprestasi membawa konsekuensi terhadap timbulnya hak pihak yang dirugikan untuk menuntut pihak yang melakukan wanprestasi untuk memberikan ganti rugi, sehingga oleh hukum diharapkan agar tidak ada satu pihak pun yang dirugikan karena wanprestasi tersebut.

Wanprestasi timbul dari adanya persetujuan atas agreement. Artinya untuk mendalilkan suatu subjek hukum telah wanprestasi, harus ada terlebih dahulu suatu perjanjian yang dibuat oleh para pihak yang telah memenuhi syarat-syarat dalam Pasal 1320 KUHPerdata, baik syarat subjektif maupun syarat objektif.

Pasal 1266 KUHPerdata ${ }^{9}$ menjadi salah satu pasal yang mengatur pembatalan perjanjian sebagai akibat adanya wanpretasi dilakukan pembatlan melalui pengadilan, yaitu:

"Syarat batal dianggap selalu ditancumkan dalam persetujuanpersetujuan yang bertimbal balik, manakalah salah satu pihak tidak memenuhi kewajibannya". "Dalam hal demikian persetujuan tidak batal demi hukum, tetapi pembatalan harus dimintakan kepada hakim".

"Permintaan ini juga harus dilakukan meskipun syarat batal mengenai tidak terpenuhinya kewajiban dinyatakan di dalam perjanjian"."Jika syarat batal tidak dinyatakan dalam persetujuan, hakim adalah leluasa 
untuk, menurut keadaan, atas permintaan si tergugat, memberikan suatu jangka waktu mana, namun tidak lebih dari satu bulan”.

Syarat batal pada pasal ini hanya khusus mengatur ketika terjadi wanprestasi, tidak yang lain. Prinsipnya, Pasal 1266 KUHPerdata ini ingin memberikan suatu kewajiban (mau tidak mau) bahwa bagaimanapun para pihak mengatur suatu perjanjian timbal-balik (das Sein), namun apabila berkaitan dengan batalnya perjanjian sebagai akibat wanprestasi, perjanjian tersebut harus tunduk pada ketentuan Pasal 1266 KUHPerdata (das Sollen). Kewajiban yang tidak dapat ditawar-tawar sebagaimana diatur dalam Pasal 1266 KUHPerdata terlihat dari penggunaan kata "dianggap selalu“. Artinya, ada atau tidaknya klausula mengenai batalnya perjanjian sebagai akibat wanprestasi, maka ketentuan yang berlaku adalah ketentuan Pasal 1266 KUHPerdata tersebut.

Peranan lembaga peradilan atau Hukum merupakan suatu kebijakan atau aturan yang berfungsi untuk mengatur tingkah laku masyarakat serta menjadi salah satu pedoman bagi penggerak bangsa dalam melakukan tugasnya. Menurut Soebekti tujuan didirikannya hukum adalah menyelenggarakan keadilan demi kehidupan bermasyarakat yang adil dan makmur.

Proses penyelesaian pemasalahan melalui pengadilan dapat memberikan jaminan bahwa hak-hak debitur dapat terlindungi secara hukum tanpa dipengaruhi oleh adanya kedudukan yang dominan dari para pihak yang terikat dalam hubungan hukum sebagai akibat yang ditimbulkan oleh perjanjian yang dibuat. Dalam hal perjanjian kredit tentunnya posisi dominan bank akan lebih menentukan isi suatu perjanjian itu. Oleh sebab itu, sering dijumpai perjanjian kredit memiliki sifat berbentuk baku dengan klausula yang telah ditentukan oleh bank.

Dalam kajian teori tradisional, tiap hak seorang individu mengandung "klaim" atas pelakuan individu lain, yakni atas perlakukan yang 
diwajibkan individu kedua kepada individu yang pertama ${ }^{10}$. Oleh sebab itu, proses penyelesaian sengketa wanprestasi diluar pengadilan yang mendasari pada perjanjian yang dibuat dengan mengesampingkan Pasal 1266 dan Pasal 1267 KUHPerdata memberikan implikasi-implikasi yuridis hilangnya hak-hak debitur, di mana debitur dalam kedudukan lebih lemah dibandingakn dengan bank sebagai kreditur akan lebih menguntungkan dan membuat bank lebih dominan dalam mengambil keputusan-keputusan sebagai solusi penyelesaian permasalahan wanprestasi. Pilihan-pilihan alternatif yang akan diambil lebih dominan merupakan pilihan dari pihak bank dibandingkan pilihan pihak debitur. Selain itu, implikasi yuridis yang lain atas hak-hak debitur adalah debitur kehilangan hak hukum untuk memperoleh suatu putusan pengadilan yang memberikan kedudukan yang seimbang, debitur tidak dapat melakukan upaya untuk mempertahankan hak-hak hokum termasuk gugatan-gugatan ganti rugi atas kerugian yang dialami debitur.

Hakim sebagai pihak pemutus perkara sangat berperan sebagai penentu masa depan hukum, karena setiap putusan hakim akan menjadi pusat perhatian masyarakat. Hakim tidak hanya berperan sebagai corong undang-undang, tetapi hakim juga berperan sebagai penemu hukum (recht vinding), sesuai dengan nilai-nilai budaya yang hidup di masyarakat, terutama nilai-nilai Pancasila. Hakim harus mengadili dengan benar terhadap perkara yang diajukan kepadanya, hakim tidak boleh menolak suatu perkara dengan alasan hukum tidak ada atau belum jelas, melainkan wajib mengadilinya. Sebagai penegak hukum hakim wajib menggali, mengikuti dan memahami nilai hukum yang hidup dalam masyarakat.

Hakim dalam memutus perkara perdata harus dapat memenuhi rasa keadilan bagi masyarakat, dalam hal memutus suatu perkara hakim mempunyai kebebasan, hal ini sesuai dengan salah satu unsur Negara hukum yang menyatakan, bahwa adanya peradilan yang bebas dan tidak

${ }^{10}$ Han Kelsen, Teori Hukum Murni Dasar-Dasar Ilmu Hukum Normatif, Cetakan XVI 2014. Bandung: Penerbit Nusa Media, 2014. hlm. 153. 
memihak. Hakim selain memperhatikan ketentuan yang tertulis dalam undang-undang juga memperhatikan hukum yang hidup dalam masyarakat serta menggunakan hati nurani yaitu berdasarkan hakim dan rasa keadilan masyarakat.

Hakim memegang peranan yang sangat penting dalam suatu lembaga peradilan. Hakim sebagai penegak hukum dan keadilan, serta sebagai pejabat negara yang mempunyai tugas mulia dalam mewujudkan negara hukum, memberikan kepastian hukum, dan kemanfaatan bagi masyarakat melalui putusan hukumnya di pengadilan. Putusan hakim adalah penemuan hukum dalam arti khusus mengandung pengertian proses dan karya yang dilakukan oleh hakim, yang menetapkan benar dan tidak benar menurut hukum dalam suatu situasi konkret.

Tindakan hakim dalam memerikasa dan memutuskan perkara adalah merupakan rangkaian kegiatan penegakan hukum untuk mengakhiri suatu sengketa yang terjadi dalam kehidupan masyarakat untuk mewujudkan suatu keadilan hukum. Dalam melaksanakan penegakan hukum, Pasal 27 Undang-Undang Nomor 14 Tahun 1970 tentang ketentuan-ketentuan pokok kekuasaan kehakiman, mewajibakan hakim untuk menggali, mengikuti dan memahami nilai-nilai hukum yang hidup di dalam masyarakat.

Adapun peranan hakim dalam upaya-upaya memberikan perlidungan hukum kepada pihak-pihak melalui lembaga peradilan, terbagi menjadi menjadi dua, yaitu:

\subsubsection{Bidang Non Litigasi}

Bidang non litigasi yaitu berbagai tindakan yang dilakukan hakim (dalam hal ini ketua pengadilan negeri) menangani berbagai masalah yang berkaitan dengan pelaksanaan perjanjian kredit bank. Misalnya, penyampaian somasi, penyitaan barang jaminan, aannmaning, sita eksekusi, pelelangan dan pengosongan; tindakan pencegahan seperti 
legalisasi dan waarmerking tergolong bidang ini. Tindakan hakim ini dilakukan tanpa didahulukan persidangan. ${ }^{11}$

\subsubsection{Bidang Litigasi}

Bidang litigasi, yaitu pemutusan sengketa melalui putusan hakim. Litigasi dalam bahasa inggris sebagai "to bring a law suit against someone to have dispute settled", yang artinya diuraikan sebagai "upaya mengajukan gugatan terhadap seseorang untuk mendapatkan putusan".

Ditinjau dari peranan dan aspek hukum atas peran hakim dalam kajian penulis tentang pengesampingan Pasal 1266 dan Pasal 1267 KUHPerdata dalam perjanjian kredit bank sebagai perjanjian baku serta implikasi yuridis bagi hak-hak debitur, maka mendasari pada pandangan Sluyter, ${ }^{12}$ yang menyatakan bahwa hakim memliki 3 (tiga) peranan sebagai cara melakukan kontrol terhadap penggunaan perjanjian kredit baku "standard contract" dalam dunia perbankan sebagai berikut:

5.3.1. Pertama-tama dipertanyakan apakah formulir sebagai bentuk perjanjian baku atau standard contract dapat diterapkan, dalam hal seorang debitur menandatangani perjanjian kredit yang telah dibuat dalam bentuk formulir tanpa memahami terlebih dahulu atau mengerti dengan baik dan benar atas isi perjanjian. Hal ini dikarenakan adanya ketentuan dalam Pasal 6.5..1.3 N.B.W sebagai landasan untuk dapat dilakukan pembatalan jika perjanjian pihak lawan pada saat menandatangani perjanjian itu merasa tidak cukup mendapatkan penjelasan dangan memahami tentang isi perjanjian itu. Selain itu, pembatalan dapat dibenarkan kerena penerimaan dari suatu penundukan secara umum yang dipaksakan (een algemene onderwerping van de adherent) mengandung suatu resiko yang harus dipikul pihak lain.

\footnotetext{
${ }^{11}$ P Panggabean, Op. Cit. hlm. 87.

${ }^{12}$ Ibid. hlm. 90.
} 
5.3.2. Sebagai alat kontrol atas peraturan dalam perjanjian, ketentuan yang mengatur "standard contract" yang bersifat meragukan (bij twiffel) harus menguntungkan pihak lawan yang dipaksakan (contra preferenttem).

5.3.3. Pasal 6.5.1.3 N.B.W hakim dapat memutuskan janji-janji mana yang telah diterima sebagai kewajiban daan janji-janji mana yang harus ditolak karena dianggap terlalu berat atau tidak bisa untuk dilaksanakan.

Mengutip Sudikno Martokusumo, dalam pandangannya menyatakan bahwa "penegakan hukum" adalah sebagai pelaksana atau penegakan Undang-Undang. ${ }^{13}$

Berdasarkan pada urain-uraian diatas bahwa peranan peradilan mengenai sengketa dan/atau menyelesaikan permasalahan yang berkaitan dengan perjanjian kredit perbankan untuk memberikan suatu perlindungan hukum bagi pihak yang lemah kedudukannya dalam proses perjanjian kredit yang dibuat baik itu sebagai bank sendiri maupun sebagai nasabah bank.

Perlindungan hukum merupakan gambaran dari bekerjanya fungsi hukum untuk mewujudkan tujuan-tujuan hukum, yakni keadilan, kemanfaatan dan kepastian hukum. Perlindungan hukum adalah suatu perlindungan yang diberikan kepada subyek hukum sesuai dengan aturan hukum, baik itu yang bersifat preventif (pencegahan) maupun dalam bentuk yang bersifat represif (pemaksaan), baik yang secara tertulis maupun tidak tertulis dalam rangka menegakkan peraturan hukum.

Selanjutnya peranan peradilan lainya selain sebagai kotrol dan untuk memberikan suatu perlindungan hukum bagi pihak yang memiliki kedudukan yang lemah. Peranan peradilan juga untuk memberikan keseimbangan dan memberikan kedudukan hukum atas hak-hak hukum pihak-pihak yang lemah atau yang dirugikan sebagai bagian dari akibat yang ditimbulkan dari adanya perjanjian kredit perbankan yang dibuat

\footnotetext{
${ }^{13}$ Ibid. hlm. 88 .
} 
baik pada proses melaksanakan isi perjanjian maupun dalam proses penyelesaian permasalahan hukum sebagai akibat dari adanya perjanjian.

Oleh sebab itu, sangatlah mendasar bahwa dalam permasalahan wanprestasi sebagai syarat batal dalam perjanjian yang diatur dalam Pasal 1266 KUHPerdata merupakan suatu aturan yang wajib dan tidak dapat ditawar serta dikesampingkan oleh para pihak melalui klausula-klausula dalam perjanjian baku kredit perbankan, Pasal 1266 KUHPerdata merupakan pasal yang mengatur secara tegas tentang tata cara penyelesaian permasalahan wanpretasi melalui lembaga peradilan. Selain Pasal 1266 KUHPerdata, demikian juga dengan pasal 1267 KUHPerdata yang mengatur tentang tata cara ganti rugi sebagai akibat yang ditimbulkan dari adanya suatu perjanjian dibuat oleh para pihak di mana melalui lembaga peradilan hakim dalam perannya dan melalui putusan dapat menentukan jenis dan bentuk ganti rugi tertanggung bagi para pihak baik sebagai kreditur maupun sebagai debitur.

\section{Kesimpulan}

Pengesampingan Pasal 1266 dan Pasal 1267 KUHPerdata sebagai syarat dalam perjanjian adalah bertentangan dengan asas keadilan dan asas keseimbangan. Asas keadilan sebagaimana menurut Rawls adalah tidak adil mengorbankan hak dari satu atau beberapa orang hanya demi keuntungan ekonomis yang lebih besar bahkan suatu keadilan menurutnya harus dipahami sebagai fairness, dalam arti "kesetaraan kedudukan dan hak" bukan dalam arti "kesamaan hasil" yang dapat diperoleh semua orang.

Dengan kata lain, keadilan yang dimaksud adalah keadilan yang memberikan suatu jaminan atas kesetaraan kedudukan dan hak antara bank selaku kreditur dengan debitur dalam perjanjian kredit perbankan sebagaimana juga merupakan bagian dari asas keseimbangan yang mewujudkan kesetaraan posisi yang seimbang antara hak dan kewajiban masing-masing pihak dalam perjanjian kredit baik sejak awal perjanjian dibuat sampai pada pemenuhan hak dan kewajiban yang diperjanjikan 
termasuk secara khusus hak-hak hukum dalam hal penyelesaian permasalahan hukum oleh karena wanpretasi pada pengadilan. Selaian itu, pengesampingan Pasal 1266 KUHPerdata dalam perjanjian kredit juga bertentangan dengan Pasal 1266 KUHPerdata itu sendiri, Pasal 1266 KUHPerdata mengatur bahwa dalam hal terjadinya wanprestasi dicantumkan atau tidak dicantumkannya Pasal 1266 KUHPerdatapembatalan perjanjian harus dimintakan pada pengadilan dengan demikian Pasal 1266 KHUPerdata adalah pasal yang wajib dan tidak dapat disampingkan.

Implikasi yuridis pencantuman klausula yang mengesampingkan pasal 1266 dan pasal 1267 kitab undang-undang hukum perdata dalam perjanjian kredit perbankan terkait dengan hak debitur dalam proses penyelesaian wanpretasi sebagai syarat batal pada perjanjian adalah menghapus hak-hak serta upaya-upaya hukum debitur dalam mencari keadilan. Wanprestasi membawa konsekuensi terhadap timbulnya hak pihak yang dirugikan baik sebagai kreditur maupun debitur untuk menuntut pihak yang melakukan wanprestasi untuk memberikan ganti rugi, sehingga oleh hukum diharapkan agar tidak ada satu pihak pun yang dirugikan karena wanprestasi tersebut. 


\section{DAFTAR PUSTAKA}

\section{Literatur Ilmiah}

Abdul kadir Muhammad, Hukum Perdata Indonesia, Bandung, citra aditya bakti. 1993.

Agus Yudha Hernoko, Hukum Perjanjian Asas Proposionalitas dalam Kontrak Komersial, Jakarta: Kencana. 2010.

Ahmad Sudiro dan Deni Bram, Hukum dan Keadilan (Aspek Nasional dan Internasional), Jakarta: PT. Raja Grafindo Perdasa. 2013.

Budiono Herlien, Ajaran Umum Hukum Perjanjian dan Penerapannya di Bidang Kenotariatan, Bandung: Citra Aditya, 200.

Budi Untung, Kredit Perbankan di Indonesia, Yogyakarta: Andi. 2005.

Badrulzaman Marium Darus, Pembentukan Hukum Nasional dan Permasalhannya. PT. Alumni. Bandung. 1980.

Badrulzaman Mariam Darus Hukum Perikatan dan KUH Perdata Buku Tiga Yurisprudensi, Doktrin, Serta Penjelasan, PT. Citra Aditya Bakti. Bandung. 2015

Badrulzama Mariam Darus, Kompilasi Hukum Perikatan, Citra Aditya Bkati, Bndung 2001.

Badrulzaman MariumDarus, Perjanjian Kredit Bank. PT. Alumni. Bandung. 1978.

Badrulzaman Mariam Darus, Hukum Perikatan Dalam KUHPerdata Buku Ketiga, Bandung: PT. Citra Aditya Bakti 2015.

Chatamarrasjid, Hukum Perbankan Nasional Indonesia, Jakarta: Kencana Prenada Media Group. 2008.

Ch. Gatot Wardoyo, Dalam Tulis Sekitar Klausula-Klausula Perjanjian Kredit, Daeng Naja, Contract Drafting, Bandung: PT.Citra Aditya Bakti.

Darmodiharjo Darji dan Shidarta, Pokok-Pokok Filsafat Hukum, Apa dan Bagaimana Filasafat Hukum Indonesia, Gramedia. Jakarta 2008.

Fajlurrahman Jurdi, Teori Negara Hukum, Malang: Setara Press, 2016.

Herlian Budiono, Ajaran Hukum Perjanjian dan Penerapannya Dibidang Kenotariatan, Bandung: Citra Aditya. 2010.

Jimly Asshiddiqie, Gagasan Kedaulatan Rakyat dalam Konstitusi dan Pelaksanaannya di indonesia, Jakarta: Ichtiar Baru Van Hoeven 1994. Kahar Masyhur, Membina Moral dan Akhlak, Jakarta: Kalam Mulia, 1985.

Kelsen Han, Teori Hukum Murni Dasar-Dasar Ilmu Hukum Normatif, Cetakan XVI 2014. Penerbit Nusa Media. Bndung 2014.

Kelsen Hans, General Theory Of Law And State, diterjemahkan oleh Rasisul Muttaqien, Bandung: Nusa Media, 2011.

Komaria, Hukum Perdata, Malang. Malang Universitas Muhammadyah, 2002.

Khairandy Ridwan, Itikad Baik Dalam Kebebasan Berkontrak, FH UI. Pascasarjana. 2003. 
L. Moleong, Metode Penelitian Kualitatif. Bandung: PT Remaja Rosdakarya, 2002.

M. Bahsan S.H., S.E., Hukum Jaminan dan Jaminan Kredit Perbankan Indonesia, Jakarta: PT. Raja Grafindo Persada, 2007.

Mukti Fajar ND dan Yuliato Ahmad, Dualisme Penelitian Hukum Normatif dan Hukum Empiris, Yogyakarta: Pustaka Pelajar, 2010.

Majelis Permusyawaratan Rakyat Republik Indonesia, Panduan Pemasyarakatan Undang-Undang Dasar Republik Indonesia Tahun 1945 (Sesuai dengnan Urutan Bab, Pasal dan ayat), Jakarta: Sekertaris Jendral MPR RI 2010.

Moh. Kusnardi dan Harmaily Ibrahim, Hukum Tata Negara Indonesia, Jakarta: Sinar Bakti, 1988.

MarzukiPeter Mahmud, Penelitian Hukum, Jakarta, Kencana Prenada Media Group, 2005.

Munir Fuady, Teori Negara Hukum Modern (Rehctstaat), Bandung: Refika Aditama, 2009.

Masri Singarimbun dan Sofian Effendi, Metode Penelitian Sosial. Jakarta: LP3ES, 1998.

Muljadi Kartini dan Widjaja Gunawan, Seri Hukum Perikatan (Perikatan Pada Umumnya), Cetakan ke-2, Raja Grafindo Persada, 2003. Notohamidjojo O. Masalah:Keadilan, Tirta Amerta, Semarang, 1971.

Panggabean, Pratik Standar Contract (Perjanjian Baku) dalam Perjanjian Kredit Perbankan, Bandung: PT. Alumni. 2012.

Prajudi Atmosudirjo. Hukum Administrasi Negara. Jakarta: Ghalia Indonesia, 1994.

Purnadi Purbacaraka dan Soerjono Soekanto, Renungan Tentang Filsafat Hukum, Jakarta, Rajawali, 1982.

Ratna Artha Windari, Hukum Perjanjian, Yogyakarta: Graha Ilmu. 2014.

Rusli Hardijan, Hukum Perjanjian Indonesia Dan Common Law, Pustaka Sinar Harappan, Jakarta. 1996.

Robert W. Emerson, Buseness Law, Fourth Edition, Barron's. United State 2004.

Sentosa Sembiring, Hukum Perbankan Edisi Revisi, Bandung: CV. Mandar Maju, 2012.

Subekti, Hukum Perjanjian, Jakarta: PT. Intermasa, 1996. Sutarno, Aspek-Aspek Hukum Perkreditan Pada Bank, Bandung, Alfabeta, 2003.

Soerjono Soekanto dan Sri Mamudji, Penelitian Hukum Normatif, Jakarta: PT Raja Grafindo Persada, 2004.

S. Nasution, Metode Research, Jakarta: Bumi Aksara, 2004.

Suharnoko, S.H., LL.M, Hukum Perjanjian Teori dan Analisa Kasus, Cetakan Kedua 2004. Kencana Prenada Media Group. Jakarta 2004.

Sudikno Mertokusumo, Mengenal Hukum, Yogyakarta: Liberty, 2003.

Suhrawardi K. Lunis, Etika Profesi Hukum, Cetakan Kedua, Jakarta: Sinar Grafika, 2000. 
Sjahdeini Sutan Remy, Kebebasan Berkontrak Dan Perlindungan Yang Seimbang Bagi Para Pihak Dalam Perjanjian Kredit Bank Di Indonesia, Jakarta. Institut Bankir Indonesia. 1993.

Theo Huijbers, Filsafat Hukum dalam lintasan sejarah, Cetakan ke-VIII, Yogyakarta: Kanisius, 1995.

Wacks Raymond, Jurisprudence, Blackstone Press Limited, London, 1995.

Siti Hamidah, Perwujudan Asas Keseimbangan Ke Dalam Program Linkage Perbankan syariah, Ringkasan Disertasi Program Doktor Ilmu Hukum Fakultas Hukum Universtas Brawijaya. 2017.

Arlina, Implikasi Yuridis Tentang Perjanjian Jual Beli Tanah Berikut Bangunan Yang Masih Dalam Status Jaminan Kredit Pemilikan Rumah (KPR-BTN), Tesis Program Magister Kenotariatan Fakultas Hukum Universitas Brawijaya Malang, 2008.

Latip, Perlindungan Hukum Terhadap Nasabah Bank Dalam Ketentuan Perjanjian Baku Pemberian Kredit Di Bank Pembangunan Deraha Kalaimantan Timur, Tesis Program Magister Ilmu Hukum Universitas Brawijaya Malang Tahun 2010.

Kamus Besar Bahasa Indonesia Pusat Bahasa Edisi Keempat, PT. Gramedia Pustaka Utama. Jakarta. 2008.

Arief Sidharta. 2004. "Kajian Kefilsafatan tentang Negara Hukum”, Jakarta, dalam Jentera (Jurnal Hukum), "Rule of Law", Pusat Studi Hukum dan Kebijakan (PSHK), edisi 3 Tahun II.

Pan Mohamad Faiz. 2009Teori Keadilan John Rawls, Jurnal Konstitusi, Volue 6.

S.F Marbun, Negara Hukum dan Kekuasaan Kehakiman, Jurnal Hukum Ius Quian Iustum, No. 9 Vol 4-1997.

\section{Internet}

Hada Siti, 2012, Teori Keadilan Menurut Para Ahli. Diambil dari: http://hadasiti.blogspot.co.id/2012/11/teori-keadilan-menurut-paraahli.html, (8 Maret 2017).

Ugun Guntari, 2011, Teori Keadilan Dalam Perspektif Hukum Nasional. Diambils dari: http://ugun-guntari.blogspot.co.id/2011/12/teorikeadilan-dalam-perspektif-hukum.html. (9 Maret 2017).

Adminerco,Mengenap Perjanjian Kredit. Diambil dari:http://www.ercolaw.com/index.php?option=com_content\&view $=$ article\&id=57:mengenal-perjanjian-kredit\&catid=25:theproject\&Itemid=50 (15 Maret 2017).

\section{Undang-Undang}

Republik Indonesia, 1945 Undang Undang Dasar Negara Republik Indonesia, Jakarta: Sekretariat Negara.

Republik Indonesia, Kitab Undang-Undang Hukum Perdata. 
Republik Indonesia, 1998 Undang-Undang Perubahan atas Undang-Undang Nomor 7 tahun 1992 tentang Perbankan, Jakarta: Sekretariat Negara.

Republik Indonesia, 1999Undang-Undang Perlindungan Konsumen, Jakarta: Sekretariat Negara.

Republik Indonesia, 2011Undang-Undang Pembentukan peraturan Perundang undangan, Jakarta: Sekretariat Negara.

Republik Indonesia, Undang-Undang Nomor 14 Tahun 1970 tentang ketentuan-ketentuan pokok kekuasaan kehakiman. 